\author{
В. Д. ЧОПЧИК
}

\title{
ШЛЯХИ ВИРІШЕННЯ ПРОБЛЕМ КАДРОВОЇ ПОЛІТИКИ В УНІВЕРСИТЕТСЬКІЙ КЛІНІЦІ НА ПРИНЦИПАХ ДЕРЖАВНО-ПРИВАТНОГО ПАРТНЕРСТВА
}

\author{
Стоматологічний медичний центр Національного медичного університету імені О. О. Богомольця, \\ м. Київ, Україна
}

\begin{abstract}
Мета: обґрунтувати шляхи вирішення проблем кадрової політики в університетській клініці на принципах державно-приватного партнерства.

Матеріали і методи. Для досягнення поставленої мети у роботі застосовували загальнонаукові методи аналізу, синтезу, узагальнення, інтерпретації наукових даних, а також системний і структурно-срункціональний підходи. Інфрормаційною базою дослідження стали наукові праці вітчизняних і зарубіжних спеціалістів із державно-приватного партнерства та менеджменту.

Результати. Кадри визначено як один з основних ресурсів реформування університетських клінік. Розкрито причини кадрового дисбалансу в галузі охорони здоров'я і негативні наслідки цього. Показано наявність проблеми низької ефективності використання кадрових ресурсів у системі охорони здоров'я і відсутність відповідних умов для здійснення професійної діяльності медичного персоналу. Доведено, що для вирішення проблем кадрової політики в охороні здоров'я України, у першу чергу, необхідні фрінансові та матеріально-технічні ресурси, які на сьогодні можна отримати тільки за рахунок приватного інвестора. Таким чином, в існуючій економічній ситуації України для розвитку університетських клінік, як лікувальних баз університетів, необхідно переходити на державно-приватні підприємства. У статті представлено шляхи вирішення проблем кадрової політики в університетській клініці на принципах державно-приватного партнерства.

Висновки. 3 урахуванням досвіду країн Заходу та економічної ситуації в Україні обґрунтовано більш ефективні шляхи вирішення проблем кадрової політики в університетській клініці на принципах державно-приватного партнерства.
\end{abstract}

КЛЮчОВІ СЛОВА: кадрова політика; модель університетської клініки; державно-приватне партнерство.

3 точки зору Комісії ВООЗ з прав інтелектуальної власності, інновацій та громадського здоров'я (Commission of Intellectual Property Rights, Innovation and Public Health), державно-приватне партнерство (ДПП) є ефективним способом вигідно використовувати можливості державного і приватного секторів для вирішення проблем охорони здоров'я, які окремо жодна зі сторін належним чином вирішити не може [2].

Проблеми кадрового забезпечення галузі охорони здоров'я мають глобальний характер. Міжнародні експерти зазначають, що будь-які найпередовіші технології й досягнення у галузі медицини не зможуть позитивно вплинути на здоров'я населення за відсутності належно підготовлених кадрів у системі охорони здоров'я [1].

Аналізуючи шляхи реформування охорони здоров'я у світі, Всесвітня організація охорони здоров'я зробила висновок, що серед усіх організаційних змін, метою яких є підвищення ефективності системи охорони здоров'я, найбільшого успіху досягають дії, спрямовані на управління кадрами [3].

Провідну роль кадрових ресурсів у діяльності медичних систем багато дослідників пояснюють (с) В. Д. Чопчик, 2020 тим, що обсяги фрінансового та матеріально-технічного забезпечення, при створенні відповідних умов, фрормуються і відтворюються швидше, ніж кадровий потенціал [4, 7].

Мета дослідження: обґрунтувати шляхи вирішення проблем кадрової політики в університетській клініці (УК) на принципах державно-приватного партнерства.

Матеріали і методи. Для досягнення поставленої мети у роботі застосовували загальнонаукові методи аналізу, синтезу, узагальнення, інтерпретації наукових даних, а також системний і структурно-фрункціональний підходи. Інформаційною базою дослідження стали наукові праці вітчизняних і зарубіжних спеціалістів з ДПП та менеджменту.

Результати дослідження та їх обговорення. Серед основних проблем кадрової політики в охороні здоров'я України дослідники вказують на такі проблеми, як кадровий дисбаланс, проблема відновлення кадрового складу, неефективне використання робочого часу лікарів, виконання ними невластивих трудових фрункцій, низька ефективність мотивуючої системи оплати, а також низька залученість працівників до вирішення завдань, поставлених перед медичною організацією $[5,6]$. 
Втрата кадрів у системі охорони здоров'я викликана виходом на пенсію, еміграцією, відтоком 3 державного до приватного сектору охорони здоров'я.

Наприклад, у м. Києві в 2018 р., порівняно із 2008 р., кількість штатних посад лікарів-стоматологів у комунальних та державних закладах скоротили на 137,25 посади (на 9,52\%), зайнятих - на 190,50 (на 13,47 \%), кількість лікарів-стоматологів на 211 фрізичних осіб (на 12,92 \%) [8].

Серед основних причин десіциту медичних кадрів в Україні відзначаються: низька заробітна плата медичного персоналу, незадовільне фінансування закладів охорони здоров'я (303) і стан матеріально-технічної бази. Так, аналіз результатів соціологічного дослідження, проведеного нами серед лікарів-стоматологів комунальних 303 м. Києва, засвідчив, що, на думку опитаних лікарів, основними проблемами, які заважають роботі 303, є незадовільна система фрінансування $(78,2 \pm 4,1) \%$, застаріла матеріально-технічна база $(68,8 \pm 2,1) \%$, низький рівень оплати праці персоналу $(92,1 \pm 1,2) \%$ [9].

Медичні кадри працюють в умовах інфрормаційного перевантаження, частого переключення уваги, проведення складних досліджень, великої відповідальності, що призводить до стомлення, професійного вигорання. У таких умовах низька оплата праці не відповідає трудовим затратам.

Велике значення для вирішення проблем удосконалення організації діяльності закладів охорони здоров'я має правильна кадрова політика.

Низька забезпеченість кадрами і дисбаланс у структурі медичних працівників (між лікарями і сестринським персоналом; лікарями загального профрілю та вузькими фрахівцями) знижує якість медичних послуг.

Неефективне використання робочого часу лікарів також зумовлює низьку продуктивність праці. Це підтверджується невиконанням лікарями їх посадових функцій.

Через існуючу неефективну систему оплати праці працівники не орієнтовані на кінцевий результат діяльності, що призводить до зниження якості та задоволеності пацієнтів наданням медичної допомоги. Медичні працівники практично не залучені до обговорення зі своїми безпосередніми керівниками та економічною службою медичної організації критеріїв оцінки стимулюючих доплат та їх розміру.

У дослідженнях С. Г. Бойко показано, що у медичній галузі України дуже низький відсоток підготовлених менеджерів з охорони здоров'я, фрахівців 3 державного управління охороною здоров'я [1]. Управлінські посади у галузі охорони здоров'я обіймають особи, які не мають відповідної підготовки з питань економіки, фрінансування, державного управління.
Розвиток закладів охорони здоров'я, і в тому числі університетських клінік, які практично $€$ такими ж 303 в частині надання медичної допомоги, передбачає ефективну їх діяльність на принципах ДПП, яка неможлива без високопрофесійної роботи медичного персоналу.

Кадровий менеджмент в УК на принципах ДПП вимагає комплексного вирішення і $є$ необхідністю для розвитку сучасної моделі УК.

В УК на принципах ДПП, безсумнівно, необхідно реалізовувати західний підхід до оцінки лікаря як дорогого, «штучного» ресурсу і відповідні гарантії високого рівня оплати праці, але й високі вимоги до кваліфікації та відповідальності лікаря. Для УК, які надають вторинну і третинну медичну допомогу, необхідні фрахівці, які мають широке клінічне мислення.

При переході на нові організаційно-правові засади фрункціонування університетських клінік для підвищення їх конкурентоспроможності необхідним є впровадження системи безперервного профресійного розвитку персоналу з виходом на міжнародний рівень, розробка критеріїв вимірювання результатів роботи персоналу для їх оцінки.

Для розвитку кадрових ресурсів необхідним є:

- регулярне підвищення кваліфікації персоналу УК як одного 3 фракторів підвищення стійкості розвитку установи;

- навчання персоналу управлінським навичкам, менеджменту і стандартам підприємницької діяльності;

- організація навчання базовим знанням адміністративно-управлінського персоналу на сучасному рівні;

- фрормування кадрового та управлінського резерву, його навчання на республіканському та міжнародному рівні;

- розробка критеріїв вимірювання обсягу i якості роботи персоналу з метою їх оцінки і стимулювання.

Підготовка кадрів повинна бути спрямована на профресіоналізм, який визначається:

- ставленням до змін;

- професійною кваліфікацією, майстерністю в роботі та в аналізі виконання планів;

- умінням вирішувати проблеми, пов'язані із стратегічною діяльністю;

- умінням вирішувати питання, які стосуються проведення організаційних змін.

Лікарський персонал УК повинен володіти корпоративною культурою, економічними методами управління, новими технологіями, мережевими інформаційними потоками і мережевою взаємодією. Особливо це важливо для підготовки фрахівців-менеджерів, керівників відділень та Ук.

Тільки висококваліфіковані кадри, які об'єднали наукові знання і досвід практичної діяльності, зможуть забезпечити конкурентну 
перевагу інноваційної моделі УК та ефрективне впровадження у медичну практику наукових розробок.

Поряд із вищевказаними заходами досвід багатьох дослідників показує, що одним із ключових механізмів вирішення проблем кадрової політики $€$ послідовна реалізація стратегії сталого розвитку самої медичної організації, яка включає такі основні принципи, як:

- поліпшення матеріально-технічної бази УК і поліпшення умов праці медичних працівників;

- ефрективне використання кадрових ресурсів за рахунок стратегічного аналізу і планування результатів діяльності організації, забезпечення зв'язку кадрової політики зі стратегією організації, підготовки кадрів, перевірки компетентності співробітників, обміну інформацією з персоналом для отримання колективних думок про сталий розвиток організації;

- причетність персоналу до реалізації стратегії і політики організації через систему ключових персональних показників діяльності співробітників, підрозділів, інтегрованих із стимулюючою системою оплати праці;

- ефективне використання робочого часу медичного персоналу за рахунок створення стійкого виробничого середовища, яке стимулює продуктивність праці, поліпшення умов роботи персоналу та ефективне використання матеріально-технічних ресурсів УК;

- впровадження системи мотивації медичних працівників до якісного виконання професійних обов'язків, участі персоналу в плануванні процесів організації, обміну інфрормацією, внутрішньому і зовнішньому підвищенні кваліфрікації, передачі передового досвіду і под.

Одним 3 основних напрямків кадрових інновацій, які вимагають впровадження у роботу УК, $€$ також вдосконалення кадрової політики на базі концепції фрормування УК на принципах ДПП, що забезпечить сталий розвиток клінічної бази.

\section{Висновки}

Проведений аналіз дозволяє стверджувати, що система охорони здоров'я України на сучасному етапі розвитку зазнає певні кадрові проблеми, зокрема, неефективно використовується робочий час лікарів, існуюча система оплати праці не мотивує медичний персонал до підвищення якості медичної допомоги, низьким є залучення персоналу до вирішення завдань, які стоять перед медичною організацією. У статті показано, що кадрові проблеми негативно позначаються на якості медичної допомоги населенню, а також обґрунтовані більш ефективні шляхи вирішення проблем кадрової політики в університетській клініці на принципах державно-приватного партнерства.

Перспективи подальших досліджень полягають у використанні обґрунтованих більш ефективних шляхів вирішення проблем кадрової політики в університетській клініці на принципах державно-приватного партнерства при розробці оптимізованої фрункціонально-організаційної моделі стоматологічного центру, який працює на принципах державно-приватного партнерства.

\section{Список літератури}

1. Бойко С. Г. Особливості державної кадрової політики у сорері охорони здоров'я [Електронний ресурс] / С. Г. Бойко // Теорія та практика державного управління і місцевого самоврядування. - 2018. - № 1. - С. 15. - Режим доступу : http://el-zbirn-du.at.ua/ 2018_1/12.pdf.

2. Государственно-частное партнерство в сфрере здравоохранения. Международный опыт [Электронный ресурс] // Аптека. - 2017. - 28 серпня. - Режим доступа : https://www. apteka.ua/article/423444.

3. Латуха О. А. Стратегия как ключевой фактор успеха работы медицинской организации / О. А. Латуха // Вестник Новосибирского государственного педагогического университета. - 2016. - № 1. - С. 149-156. DOI: http://dx.doi. org/10.15293/2226-3365.1601.14.

4. Муравьева Н. Н. Человеческие ресурсы в системе здравоохранения в условиях модернизации / Н. Н. Муравьева, Н. А. Самарин // Наука и экономика. - 2010. - № 4. - С. 76-77.

5. Савіна Т. В. Кадрове забезпечення сорери охорони здоров' в в Україні: стан та перспективи розвитку / Т. В. Савіна // Державне управління. - 2017. - № 15. - С. 95-98.

6. Слепцова Е. В. Современные проблемы кадровой политики в сорере здравоохранения [Электронный ресурс] / Е. В. Слепцова, В. О. Гапеева // Экономика и бизнес: теория и практика. - 2016. - Т. 5, ч. 2. - С. 64-66. - Режим доступа : https://cyberleninka.ru/article/n/sovremennye-problemy-kadrovoy-politiki-v-sfere-zdravoohraneniya.

7. Роль медицинских кадров при реализации политики в области качества медицинской помощи / В. К. Попович, И. Б. Шикина, А. Г. Турчиев, Т. Н. Бакланова // Социальные аспекты здоровья населения. - 2011. - № 1. - С. 15.

8. Чопчик В. Д. Аналіз стану стоматологічної допомоги населенню м. Києва у медичних закладах комунальної та державної форм власності / В. Д. Чопчик, Н. М. Орлова // Україна. Здоров'я нації. - 2019. - № 1 (54). - С. $120-125$. 9. Чопчик В. Д. Проблеми та шляхи удосконалення організації роботи університетського стоматологічного центру за матеріалами соціологічного опитування лікарів / В. Д. Чопчик // Медичні перспективи. - 2019. - T. XXIV, № 3. C. $122-129$. 


\section{References}

1. Boiko, S.H. (2018). Osoblyvosti derzhavnoi kadrovoi polityky u sferi okhorony zdorovia [Special features of the sovereign personnel policy in the field of health protection]. Teoriia ta praktyka derzhavnoho upravlinnia i mistsevoho samovriaduvannia - Theory and Practice of the Sovereign Government and the Government Self-determination, 1, 15. Retrieved from: http://el-zbirn-du.at.ua/ 2018_1 / 12.pdf [in Ukrainian].

2. (2017). Gosudarstvenno-chastnoye partnerstvo v sfere zdravookhraneniya [Public-private partnership in the field of healthcare]. Mezhdunarodnyy opyt. Apteka - International experience. Pharmacy, 33 (1104). Retrieved from: https: // www. apteka.ua/article/423444 [in Russian].

3. Latukha, O.A. (2016). Strategiya kak klyuchevoy faktor uspekha raboty meditsinskoy organizatsii [Strategy as a key factor in the success of a medical organization]. Vestnik Novosibirskogo gosudarstvennogo pedagogicheskogo universiteta - Bulletin of the Novosibirsk State Pedagogical University, 1, 149-156 [in Russian].

4. Muravyova, N.N., \& Samarin, N.A. (2010). Chelovecheskiye resursy v sisteme zdravookhraneniya v usloviyakh modernizatsii [Human resources in the healthcare system under modernization]. Nauka i ekonomika - Science and Economics, 4, 76-77 [in Russian].

5. Savina, T.V. (2017). Kadrove zabezpechennia sfery okhorony zdorovia v Ukraini: stan ta perspektyvy rozvytku [Personnel provision of health care in Ukraine: the state and prospects of development]. Derzhavne upravlinnia - State Administration, 15, 95-98 [in Ukrainian].

6. Sleptsova, Ye.V., \& Gapeeva, V.O. (2016). Sovremennyye problemy kadrovoy politiki v sfere zdravookhraneniya [Modern problems of personnel policy in the field of health]. Ekonomika i biznes: teoriya i praktika - Economics and Business: Theory and Practice, 5 (2), 64-66. Retrieved from: https://cyberleninka.ru/article/n/ sovremennye-problemy-kadrovoypolitiki-v-sfere-zdravoohraneniya [in Russian].

7. Popovich, V.K., Shikina, I.B., Turchiev, A.G., \& Baklanova, T.N. (2011). Rol meditsinskikh kadrov pri realizatsii politiki v oblasti kachestva meditsinskoy pomoshchi [The role of medical personnel in the implementation of policies in the field of quality of medical care]. Sotsialnyye aspekty zdorovya naseleniya - Social Aspects of Public Health, 1, 15 [in Russian]. 8. Chopchik, V.D., \& Orlova, N.M. (2019). Analiz stanu stomatolohichnoi dopomohy naselenniu m. Kyieva u medychnykh zakladakh komunalnoi ta derzhavnoi form vlasnosti [Analysis of dental care for the population of Kyiv at medical facilities of municipal and state ownership]. Ukraina. Zdorovia natsii - Ukraine. Health of Nation, 1 (54), $120-125$ [in Ukrainian]. 9. Chopchyk, V.D. (2019). Problemy ta shliakhy udoskonalennia orhanizatsii roboty universytetskoho stomatolohichnoho tsentru za materialamy sotsiolohichnoho opytuvannia likariv [The problems and ways of improvement of university dental center work management by the materials of the sociological doctors' survey]. Medychni perspektyvy - Medical Prospects, XXIV (3), 122-129 [in Ukrainian].

\section{WAYS TO RESOLVE PROBLEMS OF PERSONNEL POLICY IN UNIVERSITY CLINIC ON THE PRINCIPLES OF PPP}

V. D. Chopchyk

Dental Medical Center of O. Bohomolets National Medical University, Kyiv, Ukraine

Purpose: to substantiate solutions of the problems of personnel policy in a university clinic (UC) on the principles of public-private partnership (PPP).

Materials and Methods. To achieve this goal, the work used general scientific methods of analysis, synthesis, interpretation of scientific data, as well as systemic and structural-functional approaches. The information base of the study was the scientific works of domestic and foreign specialists in PPP and management.

Results. The article identifies personnel as one of the main resources for reforming university clinics. The causes of personnel imbalance in healthcare and the negative consequences of this are disclosed. It is shown that there is a problem of low efficiency in the use of human resources in today's healthcare and the lack of appropriate conditions for professional work. It is proved that in order to solve the problems of personnel policy in the healthcare of Ukraine, first of all, appropriate resources are required, both financial and material and technical. At present, the required resources can be obtained only at the expense of a private investor. Thus, in the current economic situation in the country, for the development of university clinics as medical facilities for universities, it is necessary to switch to PPP. The ways of solving the problems of personnel policy in a university clinic on the principles of public-private partnership are presented in the article.

Conclusions. According to the experience of Western countries and the economic situation in Ukraine more effective ways to solve the problems of personnel policy in a university clinic on the basis of PPP are substantiated.

KEY WORDS: personnel policy; model of a university clinic; public-private partnership.

Рукопис надійшов до редакції 28.11.2019 р.

\section{Відомості про автора:}

Чопчик Віталій Дмитрович - кандидат медичних наук, в. о. заступника директора з медичної частини Стоматологічного медичного центру Національного медичного університету імені О. О. Богомольця; тел.: +38(067) 383-34-23. 